\title{
織布の透湿性および通気性に及ぼす糸間隙の孔の影響
}

\author{
東京家政大学家政学部 金綱 久明・柏原 洋子・川村 綾

\section{Effects of the Inter-Yarn Pores on the Moisture and Air Permeability of Textile Fabrics}

\author{
Hisaaki Kanetsuna, Yoko Kashiwabara, and Aya Kawamura
}

Tokyo Kasei University, Kaga, Itabashiku, Tokyo, 173 Japan

\begin{abstract}
The effects of the inter-yarn pores on the moisture and air permeation through textile fabrics were investigated by the water method and KES method for three kinds of fabric groups, spun yarn fabrics and filament yarn ones as well as stainless steel meshes. Their moisture permeability measured under various environmental humidity conditions at $20{ }^{\circ} \mathrm{C}$ were discussed in relation to the pore size of the sample. The bi-logarithmic plot of the mean area per pore and the moisture permeability per unit pore area showed a linear relationship with a negative gradient, the line of which shifted in parallel toward a region of higher permeability as the environmental humidity was decreased. Comparing the moisture permeation behavior of the sample fabrics under the same condi. tion revealed that the permeability was larger in the order of the steel mesh group. the spun yarn fabric group. and the filament yarn fabric one. Similar relation of order was found also in the slope of the linear dependency above. The relations between the pore size and air permeability of the fabrics were also studied together.
\end{abstract}

(Received July 8, 1993)

\section{1. 腥 吉}

前報(1)で，ウォーター法を用いた織布の透湿では、 布両面の水蒸気濃度差の影篔が非常に大きく，等温系に おける実験では，織布の透湿における系に及は寸測定温 度の影翌の殆どは，系の測定温度を変えることによる布 兩面の水蒸気濃度差の変化によることを報告した。織布 の透湿に関しては数多くの研究がなされており，従来， 糸間腙，栍維間隙での水蒸気の拡散抗よび辕維中への水 分の吸湿，抬散，脱湿による水分の移動が考えられてい る。しかし，糸間陌の孔（たて系とよこ禾で井まれた 孔）を通しての水蒸気の拡散と，系中の織維と緉維の間 陌を通しての水蒸気の拡散の区別が必ずしも明確になっ ていない。そこで,織布の透湿機構を解明するため，まず。 系間隙の孔の透湿に及はす影䇺を検討することにした。

このような場合のモデル奏験として，水蒸気を通さな い真鐙板を用い，板の厚さ，四形の孔の直径，板面棈当 りの孔の数を変えここれらが，孔を通しての透湿に及は す影響を研究したM. E. Whelanら [2]の研究がある。こ の研究の透湿試験法はウォーター法であり，透湿面積 に対応する円板中の孔の数 $\mathrm{N}$, 孔の直径 d, 板の厚さを Tとして，3つの变数のうち，2つを一定にして残りの
1つを変えた場合（3通り）の透湿抵抗 $R[3]$ を求め， $\mathrm{R}$ と上記 3 通りの場合についての $\mathrm{N}, \mathrm{d} ， \mathrm{~T}$ との関係を

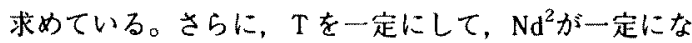
るようにNとdを变化させた場合、 $\mathrm{R}=\mathrm{a}_{3} \mathrm{~d}+\mathrm{b}_{3}\left(\mathrm{a}_{3}\right.$ お よび $\mathrm{b}_{3}$ は一定の值) の関係を得ている。 $\mathrm{Nd}^{2}$ は孔の総 面積に相当し，5通り（透湿面積に対して，0.1，1.0， $5.0,10.0,40.00$ 各\%）の場合について上記関係が得 られている。このことは，厚さが一定で，透湿面積に対 する孔の総面皘の比率が同じならば，Rはdに比例する。 すなわち，孔が大きくて，数が少い方が，孔が小さくて， 数が多い場合よりRが大きい，換言すれば透湿しにくい ことを示した。

一方，丹羽ら[4]は，アルミ䇴に1個の孔をあけ，そ の直径を変えて，ウォ一ター法のカップの透湿面積に対

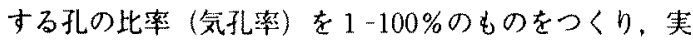
験し，その透湿量および透湿率は，無風時，有風時のい ずれの場合も，気孔率の増加とともに直楾的に堌加する ことを示した。また，金網の孔のたてよこの寸法から 求めた孔 1 個の面樍と 1 in 当りの孔の個数から計算し た気孔率が43.9-99\%のむのについて，透湿量および透 湿率を求めた。その值は，無風のときも有風のときも， 気孔率90\%付近まで有意差が認められない，さらに，綿 
およびアクリル織物についても気孔率が90\%ぐらいまで は、無風時，有風時とも気孔率の変化による差異か認め られず，金網，織物とも気孔率 $90 \%$ 以上で急激に透湿量 が增加するという結果を得ている。また，各気孔率にお いて，金網の方が織物より透湿量が低くなることを報告 している。

織布の透湿ということを考えるとき，当然のことであ るが，通常，透湿面積として，透湿カップの試料取り付 け場所の面積を用い，透湿度，透湿抵抗の計算を行って いる。M. E. Whelan ら，丹羽らもこれに準じている。 しかし，織布の透湿機構としてて，系間覍の孔の透湿に及 ほす影響を考えるとき，特に，水蒸気を通さない材料を 釆の替わりとしたモデル試料を用いるときは，糸間隙の 孔の水蒸気の通過速度，すなわち，孔の単位面積当りの 透湿度を求め万方が合理的である。このような観点から， 本研究では, 光学影微鏡で糸間隙の孔が認められ，その 大きさが異なる種々の織布および線（針金）中に水蒸気 を通さないメッシュの異なるステンレスメッシュを用い, 系(線) 間隙の孔の単位面皘当りの透湿度を求め孔の大 きさとの関係を調べ，さらに，系で構成される織布とス テンレス線からなるステンレスメッシュの違いを比較検 討し，系と線の違いを調べた。合わせて，通気性につい ても，系（線）間隙の孔の単位面積当りの通気度を求め， 孔の大きさとの関係を調べ，さらに，織布とステンレス メッシュを比較検討し，系と線の違いを調べた。

このような研究を行う場合，系（線）間隙の孔の深さ， 换言すれば䅧布，ステンレスメッシュの厚さがすでに述 ベているように問题になる。本研究に用いた試料の厚さ は，後述する表 $1 ， 2 ， 3$ に示してある通り，織布の場 合は0.12-0.32 mm, ステンレスメッシュの場合は, 線
が重なったところで， $0.30 \mathrm{~mm}$ を超えるものは2 敇で ある。前速の M. E. Whelan らの研究によれば，厚さ 0.12-0.32 mm でのRの変化は極く僅かである。また， 坪内[5]の孔あきブラスチックプレートを用いた透温実 験において，カップ上における透湿水蒸気の水蒸気圧分 布の測定結果をみると，カップ端の方を除いて，水蒸 気はブレートの近くではプレートに対して直角方向に搪 散しているようである。本研究で用いる試料の厚さの程 度で, かつ，米（線）間隙の孔の空気中の水蒸気の拡散 を考える場合，厚さの影㸷はあまり考えなくてもよいも のと考えた。

\section{2. 供驖料}

実験に用いた試料は表 1 に示した紡績系から成る織布 7 種，表 2 に示したフィラメント糸加ら成る織布 8 種お よび表 $3 に$ 示したステンレスメッシュ5種である。

\section{3. 実険方法}

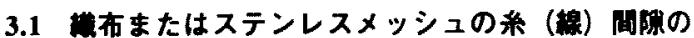 れの大きさと面程比事}

実験に用いた織布またはステンレスメッシュには，た て、よこ，の系または線（ステンレス針金）で囲まれた 孔が存在する。この孔を系（線）間隙の孔と呼ふことに し，織布またはステンレスメッシュの面と平行な面に垂 直投影される孔の形および大きさ（上から見た場合と同 様）を孔の形および大きさとする。ステンレスメッシュ の線間隙の孔はほほ正方形であり，ガーゼの糸間隙の孔 は正方形に近い形をしている。実験に用いた他の平織の 織布の系間隙の孔は，たて，よこ，の長さが異なるため 矩形か、これがくずれた形になっている。

Table 1 Details of Spun-Yarn Fabric Samples

\begin{tabular}{|c|c|c|c|c|c|c|c|}
\hline \multirow{3}{*}{$\begin{array}{l}\begin{array}{l}\text { Sample } \\
\text { fabrics }\end{array} \\
\begin{array}{l}\text { Cotton } \\
\text { broad } 40\end{array}\end{array}$} & \multirow{3}{*}{$\begin{array}{l}\text { Mass per } \\
\text { unit area } \\
\left(\mathrm{g} / \mathrm{m}^{2}\right)\end{array}$} & \multirow{3}{*}{$\begin{array}{l}\text { Thickness } \\
(\mathrm{mm}) \\
0.25\end{array}$} & \multicolumn{2}{|c|}{$\begin{array}{l}\text { Density } \\
\text { (Number } \\
/ 2.54 \mathrm{~cm} \text { ) } \\
\end{array}$} & \multirow{2}{*}{$\begin{array}{l}\text { Crimp } \\
\text { percentage } \\
(\%) \\
9.6\end{array}$} & \multirow{2}{*}{$\begin{array}{l}\begin{array}{l}\text { Yarn number } \\
\text { count } \\
\text { (tex) }\end{array} \\
15.2\end{array}$} & \multirow{2}{*}{$\begin{array}{c}\begin{array}{c}\text { Twist } \\
\text { number } \\
(\mathrm{T} / \mathrm{m})\end{array} \\
972\end{array}$} \\
\hline & & & Warp & 132.1 & & & \\
\hline & & & Weft & 63.5 & 8.4 & 15.4 & 560 \\
\hline \multirow{2}{*}{$\begin{array}{l}\text { Cotton } \\
\text { sherting }\end{array}$} & \multirow[t]{2}{*}{108.6} & \multirow[t]{2}{*}{0.27} & Warp & 89.9 & 1.8 & 19.2 & 588 \\
\hline & & & Weft & 66.0 & 26.6 & 16.2 & 748 \\
\hline \multirow{2}{*}{$\begin{array}{l}\text { Rayon staple } \\
\text { fiber muslin }\end{array}$} & \multirow[t]{2}{*}{122.4} & \multirow[t]{2}{*}{0.24} & Warp & 93.5 & 5.3 & 20.2 & 372 \\
\hline & & & Weft & 61.5 & 5.4 & 20.4 & 400 \\
\hline \multirow{2}{*}{$\begin{array}{l}\text { Polyester } \\
\text { muslin }\end{array}$} & \multirow[t]{2}{*}{131.1} & \multirow[t]{2}{*}{0.32} & Warp & 55.9 & 3.6 & 31.9 & 400 \\
\hline & & & Weft & 52.8 & 9.1 & 31.3 & 428 \\
\hline \multirow[t]{2}{*}{ Gauze } & \multirow[t]{2}{*}{33.3} & \multirow[t]{2}{*}{0.25} & Warp & 32.0 & 1.5 & 15.1 & 400 \\
\hline & & & Weft & 28.4 & 10.2 & 15.0 & 428 \\
\hline
\end{tabular}


Table 2 Details of Filament-Yarn Fabric Samples

\begin{tabular}{|c|c|c|c|c|c|c|c|}
\hline \multirow{3}{*}{$\begin{array}{l}\begin{array}{l}\text { Sample } \\
\text { fabrics }\end{array} \\
\text { Silk } \\
\text { plain gauze }\end{array}$} & \multirow{3}{*}{$\begin{array}{l}\begin{array}{l}\text { Mass per } \\
\text { unit area } \\
\left(\mathrm{g} / \mathrm{m}^{2}\right)\end{array} \\
96.6\end{array}$} & \multirow{3}{*}{$\begin{array}{c}\text { Thickness } \\
\text { (mm) } \\
0.31\end{array}$} & \multicolumn{2}{|c|}{$\begin{array}{l}\text { Density } \\
\text { (Number } \\
/ 2.54 \mathrm{~cm} \text { ) }\end{array}$} & \multirow{2}{*}{$\begin{array}{l}\text { Crimp } \\
\text { percentage } \\
(\%) \\
4.6\end{array}$} & \multirow{2}{*}{$\begin{array}{l}\text { Yarn number } \\
\text { count } \\
\text { (tex) } \\
19.7\end{array}$} & \multirow{2}{*}{$\begin{array}{r}\begin{array}{r}\text { Twist } \\
\text { numbe } \\
(\mathrm{T} / \mathrm{m})\end{array} \\
1248\end{array}$} \\
\hline & & & Warp & 59.9 & & & \\
\hline & & & Weft & 74.2 & 5.1 & 20.5 & 355 \\
\hline \multirow{2}{*}{$\begin{array}{l}\text { SILOOK } \\
\text { plain gauze }\end{array}$} & 89.7 & 0.27 & Warp & 55.9 & 1.3 & 15.9 & 1405 \\
\hline & & & Weft & 59.4 & 7.5 & 16.8 & 1467 \\
\hline \multirow{2}{*}{$\begin{array}{l}\text { Silk } \\
5 \text { yarn leno }\end{array}$} & 123.5 & 0.29 & Warp & 86.4 & 13.2 & 19.0 & 8 \\
\hline & & & Weft & 50.8 & 6.9 & 18.7 & 1077 \\
\hline \multirow{2}{*}{$\begin{array}{l}\text { SILOOK } \\
5 \text { yarn leno }\end{array}$} & 108.9 & 0.24 & Warp & 91.4 & 9.5 & 22.9 & 5 \\
\hline & & & Weft & 50.8 & 3.4 & 17.0 & 971 \\
\hline \multirow{2}{*}{$\begin{array}{l}\text { Silk } \\
3 \text { yarn leno }\end{array}$} & 122.9 & 0.28 & Warp & 86.4 & 20.4 & 21.4 & 7 \\
\hline & & & Weft & 53.3 & 7.2 & 19.3 & 973 \\
\hline \multirow{2}{*}{$\begin{array}{l}\text { Silk } 6 \text { monme } \\
\text { habutae }\end{array}$} & 24.1 & 0.08 & Warp & 153.1 & 3.0 & 3.4 & 624 \\
\hline & & & Weft & 96.5 & 1.0 & 5.2 & 0 \\
\hline \multirow{2}{*}{$\begin{array}{l}\text { Silk } 14 \text { monme } \\
\text { habutae }\end{array}$} & 59.0 & 0.12 & Warp & 136.1 & 7.2 & 6.5 & 0 \\
\hline & & & Weft & 103.1 & 4.2 & 8.6 & 3 \\
\hline \multirow[t]{2}{*}{ TEVILON * } & 124.1 & 0.23 & Warp & 56.4 & 2.4 & 33.5 & 261 \\
\hline & & & Weft & 42.7 & 2.1 & 34.5 & 304 \\
\hline
\end{tabular}

* SILOOK and TEVILON show trademarks

Table 3 Details of Steel Mesh Samples

\begin{tabular}{cccc}
\hline Sample no. & Mesh & $\begin{array}{c}\text { Nominal space } \\
\text { between wires } \\
(\mathrm{mm})\end{array}$ & $\begin{array}{c}\text { Nominal } \\
\text { diameter } \\
(\mathrm{mm})\end{array}$ \\
\hline 1 & 22 & 0.710 & 0.450 \\
2 & 30 & 0.500 & 0.350 \\
3 & 70 & 0.212 & 0.151 \\
4 & 140 & 0.106 & 0.075 \\
5 & 280 & 0.053 & 0.037 \\
\hline
\end{tabular}

図1のaは1つの乎（線）間隙の孔を示している。白 い部分が亲または線，斜線をした部分が孔である。手

(線）の中心線に点線を書いてあるが，孔の形が正方形 か矩形で大きさが同じ場合は点線で囲まれた部分のくり かえしで織布またはステンレスメッシュが形成される。 このくりかえし単位は図1のbの点線で囲まれた部分と することもできる。系（線）間隙の孔の大きさは斜線部 分の面積 $\left(\mathrm{l}_{1} \times \mathrm{l}_{2}\right)$ で表すことができ，織布またはステ ンレスメッシュ中の孔の面積比率は点線で囲まれた部分 に対する斜線部分の面積の比率

$$
\frac{l_{1} \times l_{2}}{\left(l_{1}+d_{1}\right)\left(l_{2}+d_{2}\right)}
$$

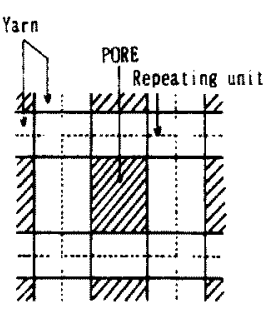

a

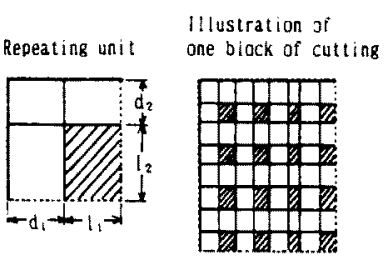

b c
Fig. 1 Illustration of the pores in a fabric (or mesh).

で表すことができる。この考え方をもとに，奏際の系 （線）間隙の孔 1 個の平均の面積 $\left(\mathrm{S}_{1}\right)$ で孔の大きさ を表し，また，上式に相当するもので孔の面積比率を表 した。具体的には次のようにした。

（1）ステンレスメッシュおよびガーゼの場合

前述のようにステンレスメッシュの線間隙の孔はほほ 正方形で表 3 に示したように公称目開き（Nominal space between wires), 公称線径 (Nominal diameter) 6 , たて、よこ，の区別がされていない。ガーゼもはほ正方 形に近い。そこでこの場合は， $\mathrm{l}_{1} \doteqdot \mathrm{l}_{2}=\mathrm{l}_{0}, \mathrm{~d}_{1} \doteqdot \mathrm{d}_{2}=\mathrm{d}_{0}$ と

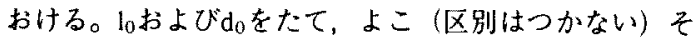
れぞれ，10か所ずつ読取顕微鏡で測定し，その平均値茢， 的をを求めた。 
系（線）間隙の孔 1 個の平均的大きさをその面皘 $\mathrm{S}_{1}$ で表し，孔の面積比率を $\mathrm{S}_{\mathrm{r}}$ とするとき， $\mathrm{S}_{1}$ および $\mathrm{S}_{\mathrm{r}}$ は 次のように表せる。

$$
\begin{aligned}
& \mathrm{S}_{1}\left(\mathrm{~mm}^{2}\right)=\overline{\mathrm{l}}_{0}^{2} \\
& \mathrm{~S}_{\mathrm{r}}=\frac{\overline{\mathrm{l}}_{0}{ }^{2}}{\left(\overline{\mathrm{l}}_{0}+\overline{\mathrm{d}}_{0}\right)^{2}}
\end{aligned}
$$

\section{（2）（1）以外の織布の場合}

すでに述べたように平織の場合は， $\mathrm{l}_{1} \neq \mathrm{l}_{2}, \mathrm{~d}_{1} \neq \mathrm{d}_{2} て ゙$ あり釆間隙の孔の形も矩形か矩形が崩れた形になってい る。そこで、このような場合は，視野に系間隙の孔が適 当な個数（原則として十数個）入るような倍率で織布を 影微鏡写真撮影し, 同倍率でスケールの影微镜写真撮影 をした。

このように，同倍率で影微鏡写真撮影した試料とスケ ールの写真を並べて乾式静電複写機で同一用紙の中心に 写し取る。写し取った用紙ら図1のcのように, 同図 bの繰り返しに相当するものになるように曲った図1c の点線に沿って用秖を切り取る（質量M）。次に，系間 隙の孔に相当する部分（図 1 c の斜線部分）を切り取 り（1 個ずつそれぞれの質量を $\mathrm{m}_{\mathrm{i}}$, 個数 $\left.\mathrm{n}\right)$, 系に相当 する部分と切り分ける。さらに、スケールの $1 \mathrm{~mm}^{2} に$ 相当する部分を切り取る(質量 $\mathrm{M}_{1} \mathrm{~mm}^{2}{ }^{2}$ )。切り取ったそ れぞれの部分の用秖を標準状態 $(20$ C，65\%RH）で状 態調節をし，その量に応じて，精度 $1 / 10 \mathrm{mg}$ 直示天科 または精度 $1 / 1000 \mathrm{mg}$ 電子天秤を用いてそれぞれの質 量を測定し，M， $\sum_{=1}^{n} m_{i}, M 1 m^{2}$ を求め，次の式により, 系間揣の孔 1 個の平均面積 $\bar{S}_{1}$ および孔の面積比率 $\mathrm{S}_{\mathrm{r}}$ を

算出した。

$$
\begin{aligned}
& \bar{S}_{1}=\frac{\sum_{i=1}^{n} m_{i}}{n \cdot M_{1} \mathrm{~mm}^{2}} \\
& \bar{S}_{r}=\frac{\sum_{i=1}^{n} m_{i}}{M}
\end{aligned}
$$

式 1 では正方形の一辺の長さの平均值を求め, その平 均值の 2 乗により采（線）間隙の孔 1 個の平均の面積を 求めており,式 3 では個々の孔の面積の平均值を求めて いることになる。従って式 $1 て ゙$ 求めた $S_{1}$ と式 3 から求 めた $\widehat{S}_{1} て ゙ は$ 同じ平均でも意味が違ってくる。ステンレ スメッシュは織布にくらべれの大きさの精度が高くでき ているので $S_{1}$ を $\bar{S}_{1}$ と同じように扱ってもさしつかえな いと考え, 両者とも $\overline{\mathrm{S}}_{1}$ で表し, $\overline{\mathrm{S}}_{1}$ と透湿度や通気度の 関係を図上に示して行くことにしガーゼについても同
様に扱うことにした。

\section{2 透湿性}

JIS-L-1099 A-2法に準じて透湿カップに試料を取り 付け (試匼体)，これを容量 $500 \mathrm{~g}$, 精度 $1 \mathrm{mg}$ の自動 電子天称にセットし，所望の温湿度に調整した人工気候 室内に置き, 試験体の質量変化を室外の測定室で 5 分ご とにプリントアウトし, 時間一質量変化の直線部分の傾 斜より透湿度 P $\left(\mathrm{g} / \mathrm{m}^{2} \mathrm{~h}\right)$ を算出した。測定方法・条件 の詳細は前報〔1〕に述べた通りである。

なお，ステンレスメッシュを所定の大きさの円形に切 って, 透湿カップに取り付ける場合は, 円形の周辺に義 歯安定剂をつけ一層の機密を図った。

\section{3 通気性}

通気性試験機 KES-F8-AP1を用いて透湿性の実験と 同様に人工気候室内で測定した。

\section{4. 実駼拮果と考察}

\section{1 布雨面の水蒸気渞度差と透湿度 P との䦌係}

人工気候室の温度 $20{ }^{\circ} \mathrm{C}$, 相対湿度 $35 \% \mathrm{RH}, 65 \% \mathrm{RH}$, $80 \% \mathrm{RH}$ ，で行った各織布の透湿度の実験結果を，織布 の下の透湿カップの水面上の空間を $100 \% \mathrm{RH}$ と仮定し. その水蒸気濃度と実験した各環境相対湿度の絶対湿度と

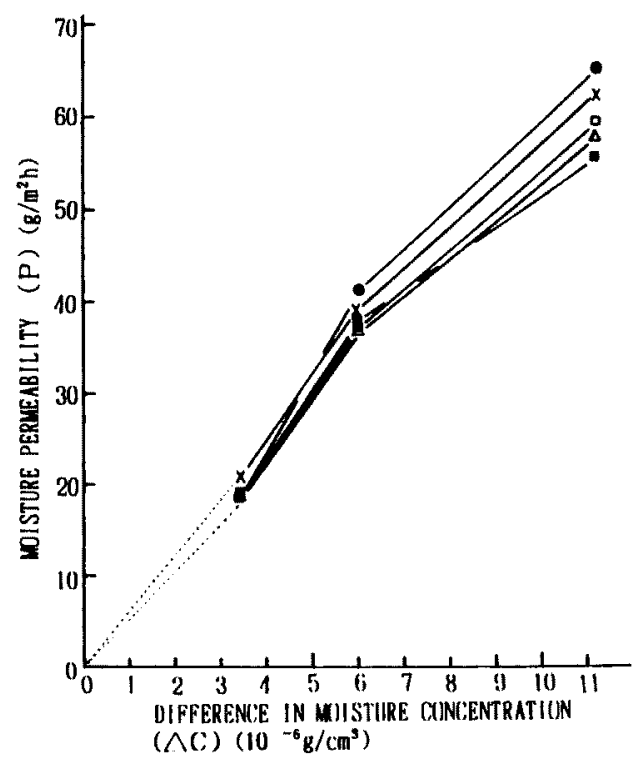

Fig. 2 Relationship between the difference, $\Delta C$, in moisture concentration on both sides of the sample fabric and the moisture permeability $\mathrm{P}$ measured at $20^{\circ} \mathrm{C}$, for the cases of spun yarn fabrics; cotton broad 40 (O), cotton shirting $(\square)$, rayon staple fiber muslin ( $\square$ ), polyester muslin $(\Delta)$, and gauze $(X)$. 


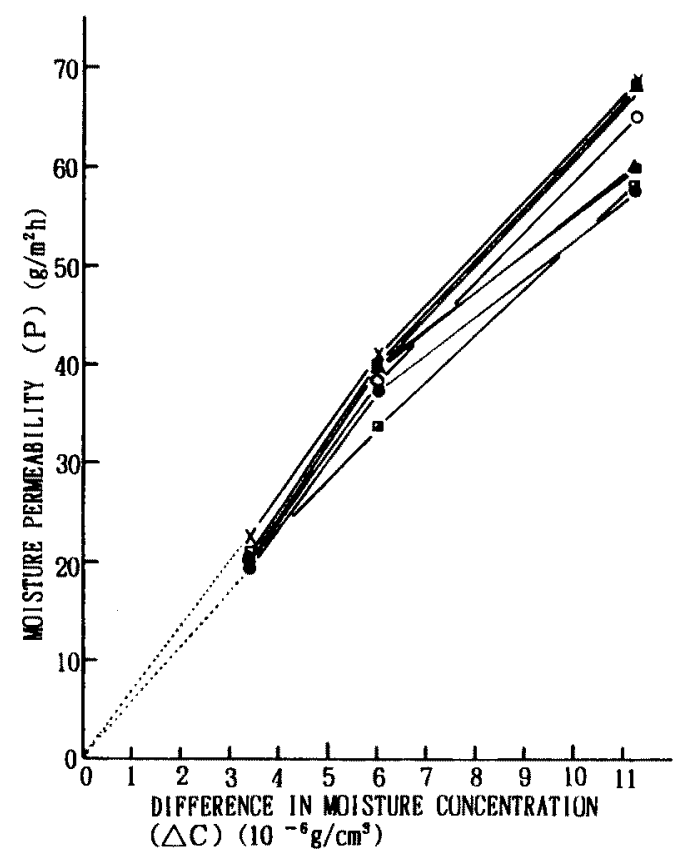

Fig. 3 Relationship between the difference, $\Delta C$, in moisture conentration on both sides of the sample fabric and the moisture permeability $\mathrm{P}$ measured at $20{ }^{\circ} \mathrm{C}$, for the cases of filament yarn fabrics; silk plain gauze (O), SILOOK plain gauze (O), silk 5 yarn leno ( $\square$ ). SILOOK 5 yarn leno ( $\mathbf{\square})$, silk 3 yarn leno $(\Delta)$, silk 6 monme habu. tae (A), silk 14 monme habutae $(X)$, and TEVILON ( $(\boldsymbol{\Delta})$.

の差，すなわち，布両面の水蒸気浱度差 $\Delta \mathrm{C}\left(10^{-6}\right.$ $\left.\mathrm{g} / \mathrm{cm}^{3}\right)$ を横軸として, 紡績系から成る織布の場合を図 2 に，フィラメント亲から成る織布の場合を図 3 に示し た。

図2, 図 3 のいずれの場合も、 $\Delta \mathrm{C}$ の增加とともに透 湿度が大きくなり，また，試料間の透湿度の差が広がっ ていることがわかる。

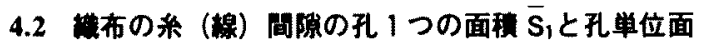
程当りの透湿度 $P_{\mathrm{u}}$ の閉保

各織布の系（線）間隙の孔 1 つの面積 $\overline{\mathrm{S}}_{1}$ と透湿度 $\mathrm{P}$ との関係の有無を検討したが，必ずしも一定の関係が見 出されなかった。そこで，糸（線）間隙の孔1つの面皘 $\bar{S}_{1}$ と孔の単位面積当りの透湿度 $\mathrm{P}_{\mathrm{u}}$ の関係を検討した。 すなわち，求めた透湿度 $\mathrm{P}$ と，前述した系（線）間隙 の孔の面積比率 $\mathrm{S}_{\mathrm{r}}$ の值加ら，孔笚位面皘当りの透湿度 $P_{u}$ を求め, $\bar{S}_{1}$ との関係を両対数グラフで示し，紡績系 加成る織布の場合を図 4 に, フィラメント采から成 る織布の場合を図 5 に示した。

図 4 からわかるように, $\bar{S}_{1}$ と $\mathrm{P}_{4}$ の両対数の間にほほ

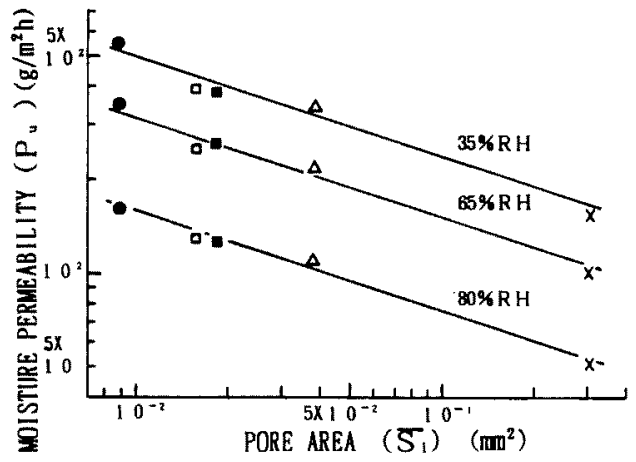

Fig. 4 Relationship between the inter-yarn pore area $\bar{S}_{1}$ and the moisture permeability, $P_{u}$, per unit pore area measured at $20^{\circ} \mathrm{C}$, for spun yarn fabrics. Symbols are defined in the same as in Fig. 2.

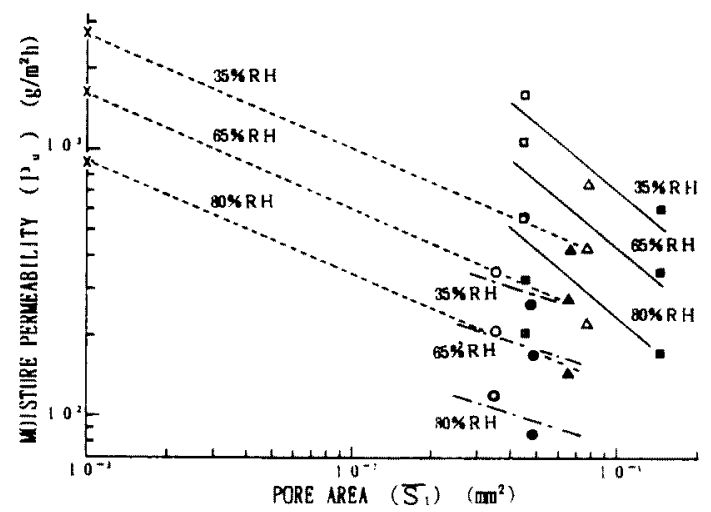

Fig. 5 Relationship between the inter.yarn pore area $\bar{S}_{1}$ and the moisture permeability, $P_{u}$, per unit pore area measured at $20{ }^{\circ} \mathrm{C}$ for filament yarn fabrics; silk or SILOOK leno (-), silk or SILOOK plain gauze (---), and plain weave fabric $(\cdots \cdots)$. The other symbols correspond to each similarly as in Fig. 3.

直線関係が成立しており， $\log \overline{\mathrm{S}}_{1}$ が小さくなるほど $\log$ $\mathrm{P}_{\mathrm{u}}$ は大きくなり，環境湿度が小さくなると，すなわち $\Delta \mathrm{C}$ が大きくなると $\log \mathrm{P}_{\mathrm{u}}$ が大きくなるように直線が ほほ平行移動している。

次に，フィラメント系から成る織布の場合は図 5 の ように，紗，絽，および平織のそれぞれの場合について 異なった傾斜の直線関係が $\overrightarrow{\mathrm{S}}_{1}$ と $\mathrm{P}_{\mathrm{u}}$ の两対数の間にほ ほ成立しており，図4の場合と同様に環境湿度が小さく なると $\log \mathrm{P}_{\mathrm{u}}$ が大きくなるように直線がほほ平行移動 している。

今，絽の場合を除いて，紡績系加ら成る織布と，フィ ラメント糸から成る織布について，同じ環境湿度の場合 


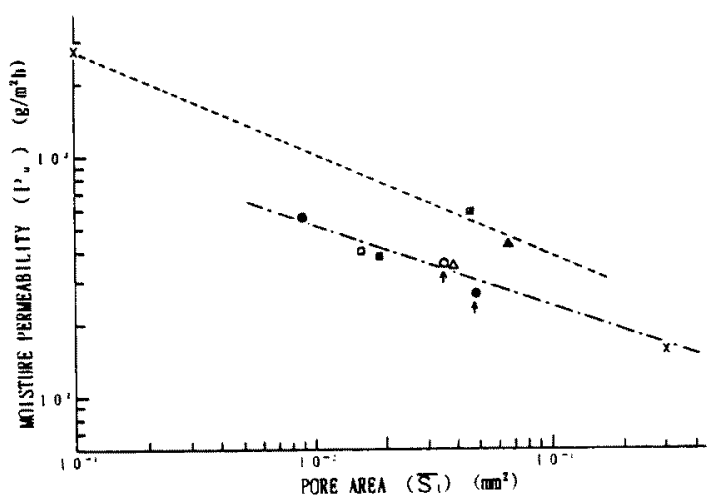

Fig. 6 Relationship between the inter-yarn pore area $\vec{S}_{1}$ and the moisture permeability, $P_{u}$, per unit pore area for spun and filament yarn fabrics under the environmental condition of $20{ }^{\circ} \mathrm{C}$ with $35 \% \mathrm{RH}$, for spun yarn fabrics (--), filament yarn fabrics (--.) , and silk or SILOOK plain gauze $(\uparrow)$. The other symbols are defined similarly as in Fig. 2 and 3.

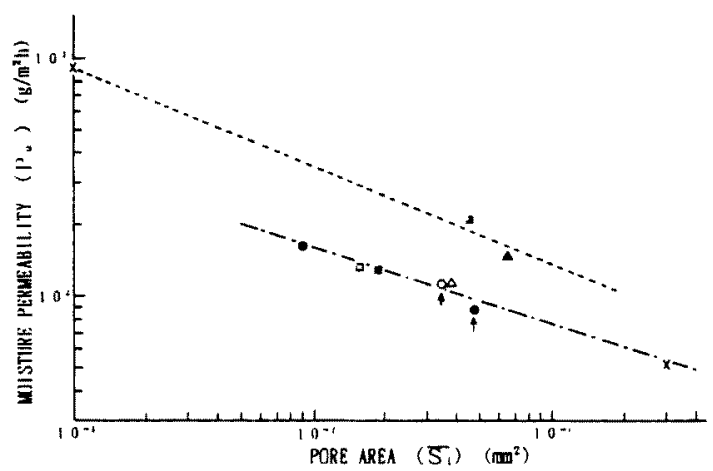

Fig. 7 Relationship between the inter-yarn pore area $\bar{S}_{1}$ and the moisture permeability, $P_{u}$, per unit pore area for spun and filament yarn fabrics under the environmental condition of $20^{\circ} \mathrm{C}$ with $80 \% \mathrm{RH}$. Symbols correspond to each in the same as in Fig. 6.

を同じ図上で比較し，図6-8に示した。図6は20 C $35 \%$ RH の場合で，フィラメント系から成る織布の結果 が紡績系から成る織布より $\log \mathrm{P}_{\mathrm{u}}$ の值が大きい位置に あり，その傾斜がやや大きくなっていることがわかる。 また、ここで興味あることは，図中に矢印を付しある租 拉よびシルックの紗が紡績系の直線上にあることである。

図 7 は20 ${ }^{\circ} \mathrm{C} ， 80 \% \mathrm{RH}$ の場合で, 図 5 の場合より $\mathrm{log}$ $P_{\mathrm{u}}$ の值が小さい位置に両直楾が移るが，図 5 の結果と 同様の傾向になっていることがかかる。

図 8 は20 ${ }^{\circ} \mathrm{C} ， 65 \%$ RH の場合で，紡績系およびフィ ラメント系から成る再布についての直楾の位置が $35 \%$

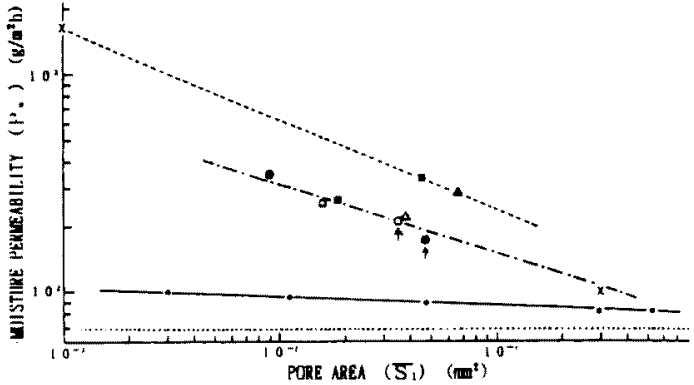

Fig. 8 Relationship between the inter-yarn pore area $\bar{S}_{1}$ and the moisture permeability, $P_{w}$, per unit pore area measured in the environment of $20{ }^{\circ} \mathrm{C}$ with $65 \% \mathrm{RH}$, for spun and filament yarn fabrics as well as stainles steel mesh; steel mesh (-) (-) and the case with no sample (…....). The other symbols are defined in the same as in Fig. 6 ,

$\mathrm{RH}$ の場合と $80 \% \mathrm{RH}$ の場合の中間の位置にあるが，両 布の相互の関係および絧およびシルックの紗が紡績系か ら成る織布の直線上にあることは前二者の場合と同様で ある。この図にはステンレスメッシュの測定結果も示し てある。また，图中の一番下の点線はカップ試料をと りつけない場合，すなわち，透湿カップの径そのものを 孔の直径とし, この孔の単位面積当りの透湿度 $\mathrm{P}_{\mathrm{u}}$ を計 算した場合の值の位置を示している。

さきに述べた M. E. Whelan ら (2)の研究では，真鍮板 について，最小孔径約 $0.6 \mathrm{~mm}$ までの孔径の大きさ，板 面積当りの孔の数，板の厚さを変え，孔を通しての透湿

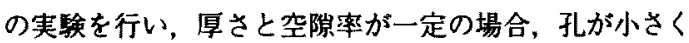
て数が大きい方が，孔が大きくて数が少ない場合より， 透湿抵抗が小さいことを示している。本実験では，ステ ンレスメッシュについて, 孔の一辺が0.1 $\mathrm{mm}$ より小さ いところまで調べているが， $\bar{S}_{1}$ と $\mathrm{P}_{\mathrm{u}}$ の耐対数の間に， その傾斜は小さいが，ほほ直線関保が成立しており， $\log \bar{S}_{1}$ が小さくなるほどlog $\mathrm{P}_{\mathrm{u}}$ が大きくなっていること がわかる。このことは[2]と同じ結果と言える。

ガーぜ（紡績系から成る織布中のX印）が通常の織布 で一番采間腙の孔が大きいと考え，これより糸間隙の孔 が小さい範囲について，ステンレスメッシュの $\log \overline{\mathrm{S}}_{1}$ と $\log \mathrm{P}_{\mathrm{u}}$ の直線関係が図の絴軸の一番低い位置に，次に 紡績采から成る織布の $\log \bar{S}_{1}-\log P_{\mathrm{u}}$ の関係を示す直線 が維軸のより高い位置にある。そして，系のより数の少 ないフィラメント系から成る織布の $\log \overline{\mathrm{S}}_{1}-\log \mathrm{P}_{\mathrm{u}}$ の関 係を示す直線が糋軸の一番高い位置にある。同じフィラ メント采から成る織布でも，系のより数がかなり多い紗 の場合は，紀績采から成る織布と同一の直線上にあるこ 


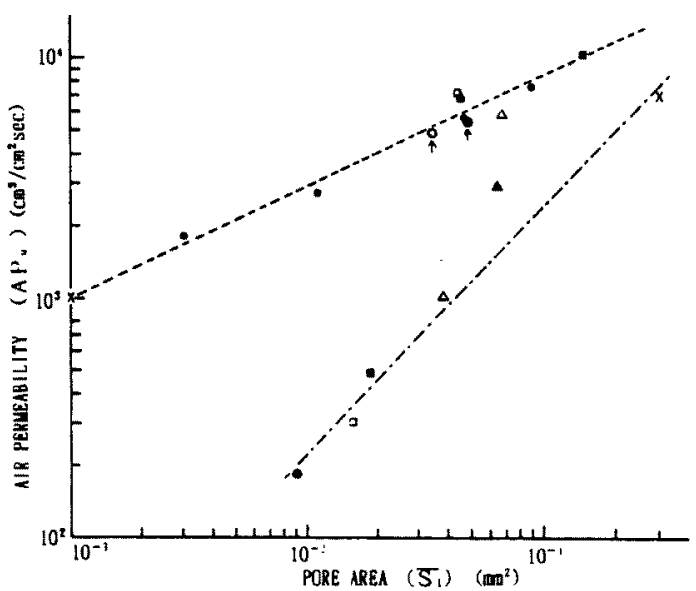

Fig. 9 Relationship between the inter-yarn pore area $\bar{S}_{1}$ and the air permeability, $\mathrm{AP}_{u}$ per unit pore area measured in the room of $20{ }^{\circ} \mathrm{C}$ with $65 \% \mathrm{RH}$, for spun and filament yarn fabrics as well as stainless steel mesh; spun yarn fabrics (-- - ) and filament yarn fabrics as well as steel mesh $(\cdots \cdots)$. The other symbols correspond to each in the same as in Figs. 8, 2, and 3.

とがかかった。

丹羽らは，気孔率を変えた木綿織物と金網の透湿量の 実験 [4]，木棉，アクリル織物と金網の過度状態の透湿 実駼(6)で金䋧の方が織物より透湿量または透湿速度定 数が小さくなることを報告しており，本研究はこれと一 致するところがある。

ステンレスメッシュの場合は線中に全く水蒸気を通さ ず，紡績糸から成る織布，秒の場合は糸のよりがかなり かかって扔り，系のより数の少ないフイラメント糸から 成る織布より系中の織維間隙を水蒸気が通りにくいと考 えられる。

なお，行った以上の実験結果からは，各图の例えば， 図 6，7，8の図中の一点鎖線中には，綿，レーヨン， ポリエチレンテレフタレート䄉維が同一直線上にあるこ とからかかるように，縺維素材の透湿への影隌は殆ど認
められなかった。このことは，通常の透湿性の実験の場 合について，丹羽[7]により指摘されていることと一致 する。

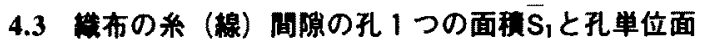
旗当たりの通気度 $\mathrm{AP}_{\mathbf{u}}$ の関係

測定した通気度を，透湿度の場合と同粎に，系（線） 間隙の孔単位面皘当たりの通気度 $\mathrm{AP}_{\mathrm{u}}$ に換算し，その 対数と系（線）間隙の孔 1 つの面積 $\overline{\mathrm{S}}_{1}$ の対数の関係を 図 9 に示した。図からかかるように,フィラメント糸か ら成る織布とステンレスメッシュが同じ直線で示され， 紡繥系から成る織布についての直線より高い位置にある。 また， $\mathrm{P}_{\mathrm{u}}$ の場合とは逆に， $\log \overline{\mathrm{S}}_{1}$ が大きくなるほど， $\log \mathrm{AP}_{\mathrm{u}}$ が大きくなっていることがわかる。このことは, 透湿が布両面の水蒸気浱度差にもとづく拡散現象であり， 通気は布雨面の圧力差による強制的空気の流れであり， 両者の現象が本質的に異なっていることをしめしている。 また，紡縝系から成る織布では，系から系（線）間隙の 孔中に出ている毛羽が通気に影響しているのに対して, フィラメント糸から成る織布およびステンレスメッシュ ではこの影響がないため，通気がよいものと推定される。

本論文は第 6 回感覚と計測に関するシンポジウム（主 催 䄉維学会 協替 日本化学会他)（1992年 6 月, 東 京，国立教育会館）において，その概要を発表した。

\section{文献}

1. 金網久明, 根本文子, 村松圭子，維学誌，49，432 (1993).

2. H. E. Whelan, L. E. MacHattie, A. G. Goodings, and L. H. Turl, Tex. Res. J., 25, 205 (1955)

3. L. Fourt and M. Harris. Tex. Res. J., 17, 256 (1947).

4. 丹羽雅子, 今井律子, 高力紀子, 家政学研究, 12 , No.1, 16 (1965)

5. 坪内紘三, 䄳維学会シンポジウム予稿集, B-78 (1990).

6. 丹羽雅子, 家政学研究, 11, No.12, 43 (1964).

7. 丹羽雅子, 家政学研究, 10, No.1, 10 (1963). 